\title{
Non-climatic signal in ice core records: lessons from Antarctic megadunes
}

\author{
Alexey Ekaykin ${ }^{1,2}$, Lutz Eberlein ${ }^{3}$, Vladimir Lipenkov ${ }^{1}$, Sergey Popov ${ }^{4}$, Mirko Scheinert $^{3}$, Ludwig Schröder $^{3}$, and \\ Alexey Turkeev ${ }^{1}$ \\ ${ }^{1}$ Climate and Environmental Research Laboratory, Arctic and Antarctic Research Institute, 38 Beringa st., \\ 199397 St. Petersburg, Russia \\ ${ }^{2}$ St. Petersburg State University, 33-35, 10th line VO, 199178 St. Petersburg, Russia \\ ${ }^{3}$ Technische Universität Dresden, Institut für Planetare Geodäsie, 01062 Dresden, Germany \\ ${ }^{4}$ Polar Marine Geological Research Expedition, 24 Pobedy st., 198412 Lomonosov, Russia \\ Correspondence to: Alexey Ekaykin (ekaykin@aari.ru)
}

Received: 11 November 2015 - Published in The Cryosphere Discuss.: 17 December 2015

Revised: 11 April 2016 - Accepted: 20 May 2016 - Published: 7 June 2016

\begin{abstract}
We present the results of glaciological investigations in the megadune area located $30 \mathrm{~km}$ to the east of Vostok Station (central East Antarctica) implemented during the 58th, 59th and 60th Russian Antarctic Expedition (January 2013-2015). Snow accumulation rate and isotope content $\left(\delta D, \delta^{18} \mathrm{O}\right.$ and $\left.\delta^{17} \mathrm{O}\right)$ were measured along the $2 \mathrm{~km}$ profile across the megadune ridge accompanied by precise GPS altitude measurements and ground penetrating radar (GPR) survey. It is shown that the spatial variability of snow accumulation and isotope content covaries with the surface slope. The accumulation rate regularly changes by 1 order of magnitude within the distance $<1 \mathrm{~km}$, with the reduced accumulation at the leeward slope of the dune and increased accumulation in the hollow between the dunes. At the same time, the accumulation rate averaged over the length of a dune wave ( $22 \mathrm{~mm}$ w.e.) corresponds well with the value obtained at Vostok Station, which suggests no additional wind-driven snow sublimation in the megadunes compared to the surrounding plateau. The snow isotopic composition is in negative correlation with the snow accumulation. Analysing dxs / $\delta D$ and ${ }^{17} \mathrm{O}$-excess / $\delta D$ slopes (where $\mathrm{dxs}=\delta D-8 \cdot \delta^{18} \mathrm{O}$ and ${ }^{17} \mathrm{O}$-excess $=\ln \left(\delta^{17} \mathrm{O} / 1000+1\right)$ $\left.-0.528 \cdot \ln \left(\delta^{18} \mathrm{O} / 1000+1\right)\right)$, we conclude that the spatial variability of the snow isotopic composition in the megadune area could be explained by post-depositional snow modifications. Using the GPR data, we estimated the apparent dune drift velocity $\left(4.6 \pm 1.1 \mathrm{~m} \mathrm{yr}^{-1}\right)$. The full cycle of the dune drift is thus about 410 years. Since the spatial anomalies of
\end{abstract}

snow accumulation and isotopic composition are supposed to drift with the dune, a core drilled in the megadune area would exhibit the non-climatic 410-year cycle of these two parameters. We simulated a vertical profile of snow isotopic composition with such a non-climatic variability, using the data on the dune size and velocity. This artificial profile is then compared with the real vertical profile of snow isotopic composition obtained from a core drilled in the megadune area. We note that the two profiles are very similar. The obtained results are discussed in terms of interpretation of data obtained from ice cores drilled beyond the megadune areas.

\section{Introduction}

Large snow and ice dunes are some of the most intriguing and spectacular phenomena in Antarctica. The first reports on the existence of the huge waves on the surface of the Antarctic ice sheet were made soon after the beginning of the extensive exploration of the Antarctic interior during the International Geophysical Year (IGY) (Dolgushin, 1958).

Since then such surface undulations have been observed in different parts of the Antarctic continent - in Adelie Land (Pettre et al., 1986), Dronning Maud Land (Anschütz et al., 2006; Eisen et al., 2005), Enderby Land (Fujita et al., 2002), Marie Byrd Land (Whillans, 1975; Gow and Rowland, 1965), Victoria Land (Frezzotti et al., 2002a, b), Queen Mary Coast (Vladimirova and Ekaykin, 2014; Dolgushin, 
1958), Wilkes Land (Black and Budd, 1964; Goodwin, 1990) - or, simply speaking, almost everywhere.

In 1988 Swithinbank suggested the term "megadunes" (Swithinbank, 1988) based on their similarity to the desert sand megadunes. At present this term is conventionally used to describe the specific dunes observed in central East Antarctica (Albert et al., 2004; Alberti and Biscaro, 2010; Fahnestock et al., 2000; Frezzotti et al., 2002b), which form a system of parallel ridges with a wavelength of $2-5 \mathrm{~km}$, amplitude of 2-8 $\mathrm{m}$ and length of up to $100 \mathrm{~km}$. One should distinguish between megadunes and other forms of periodic or "transversal" dunes that mainly form in the coastal zone of East Antarctic ice sheet and differ from megadunes in their morphology and, likely, origin.

The first observations of a relationship between the ice sheet surface topography (surface slope) and snow accumulation rate have shown that for all types of dune the snow is subjected to a very strong aeolian redistribution with the increased accumulation in the concaves and reduced accumulation on the convexities (Black and Budd, 1964). This relationship has been later confirmed in a number of studies, e.g. (Frezzotti et al., 2007; Fujita et al., 2011; Hamilton, 2004; Kaspari et al., 2004; Richardson et al., 1997; Rotschky et al., 2004; Anschütz et al., 2007; Ekaykin et al., 2002; Dadic et al., 2013). These studies have also shown that the dunes are not stagnant, but rather drift across the ice sheet surface, which does not allow the snow to simply fill in the hollows between the dunes, thus maintaining their dynamic equilibrium. The estimates of the dunes' horizontal drift velocity range from 4 to $25 \mathrm{~m} \mathrm{yr}^{-1}$ (Whillans, 1975; Frezzotti et al., 2002b; Van der Veen et al., 1999; Black and Budd, 1964).

The first dedicated ground survey of megadunes was made by Frezzotti et al. (2002b). It was shown, in particular, that snow is removed from the leeward slopes of the dunes where a specific erosional type of snow, "glaze surface", is formed. In contrast, snow accumulation is increased on the windward slopes that are characterized by the depositional types of the snow microrelief.

Since the 1980s the megadunes have been observed with the use of the satellite methods (Swithinbank, 1988; Fahnestock et al., 2000; Alberti and Biscaro, 2010; Scambos et al., 2012), which has revealed that these snow features are widely presented in Antarctica, occupying in total about $500000 \mathrm{~km}^{2}$.

The precipitated snow is not simply redistributed in the megadune area. Indeed, it is widely recognized that the winddriven sublimation is an important part of the surface-snow mass balance (Bintanja and Reijmer, 2001; Lenaerts et al., 2010; Thiery et al., 2012), removing 20 to $75 \%$ of precipitation (Frezzotti et al., 2004, 2007). In the megadunes this figure may increase to $85 \%$ (Frezzotti et al., 2004). Thus, the wide extent of the megadune fields and glaze surfaces (which occupy in total more than $10 \%$ of the continent area), where snow drift processes are intensified, must be taken into account for a correct estimate of the Antarctic surface mass balance (Scambos et al., 2012; Das et al., 2013).

Physical properties of snow in the megadune areas have been studied by Albert et al. (2004), Courville et al. (2007), Severinghaus et al. (2010) and Gregory et al. (2014). In particular, the snow erosion zones of megadunes are represented by coarse-grained snow (depth hoar) characterized by increased air permeability. The processes taking place in snow under near-zero accumulation help to understand the data on isotopic composition of gas trapped in the ice core air bubbles (Severinghaus et al., 2010). It is suggested that lowaccumulation highly permeable snow zones, similar to those currently existing in the megadune areas, covered a large extent of Antarctica in the glacial times (Dreyfus et al., 2010).

Chemical properties of the megadune snow were considered in very few studies (Dixon et al., 2013). It is noted that the surface slope may, at least in the coastal areas, affect the snow chemistry (Mahalinganathan et al., 2012).

The strong post-depositional metamorphosis of snow in the megadunes has to modify its stable water isotope properties (Courville et al., 2007; Frezzotti et al., 2002b; Neumann et al., 2005). It is also known that irregular snow redistribution by wind due to complex surface topography does affect the isotopic content of the deposited snow, which causes a poor correlation of isotopic profiles obtained at two points, separated only by a short distance (Ekaykin et al., 2014; Benoist et al., 1982; Karlöf et al., 2006). However, no systematic study of snow isotopic composition in the megadunes has been conducted up to now.

In the summer seasons of the 58th, 59th and 60th Russian Antarctic Expeditions (RAE) 2013-2015, we carried out complex glaciological investigations in the megadune area located about $30 \mathrm{~km}$ to the east of the Russian Vostok Station (Fig. 1). In this paper we analyse the spatial distribution of the snow isotope content in the megadunes.

\section{Data and methods}

\subsection{Glaciological and stable water isotope data}

In January 2013 the Vostok megadune area was visited for the first time. The accumulation-stake profile was established perpendicular to the megadune crest. The total number of stakes was 21 (named MD00 to MD20), the distance between adjacent stakes was about $100 \mathrm{~m}$ and the total length of the profile was $1983 \mathrm{~m}$ (Fig. 1). The samples of the upper $1.5 \mathrm{~m}$ of snow were also taken near each stake to be analysed for the concentration of the stable water isotopes $\left(\delta D, \delta^{18} \mathrm{O}\right.$ and $\left.\delta^{17} \mathrm{O}\right)$.

In January 2014 and January 2015 the stakes were revisited, and the repeated measurements of their heights and surface-snow density allowed us to obtain the amount of snow accumulated over two years (January 2013-January 


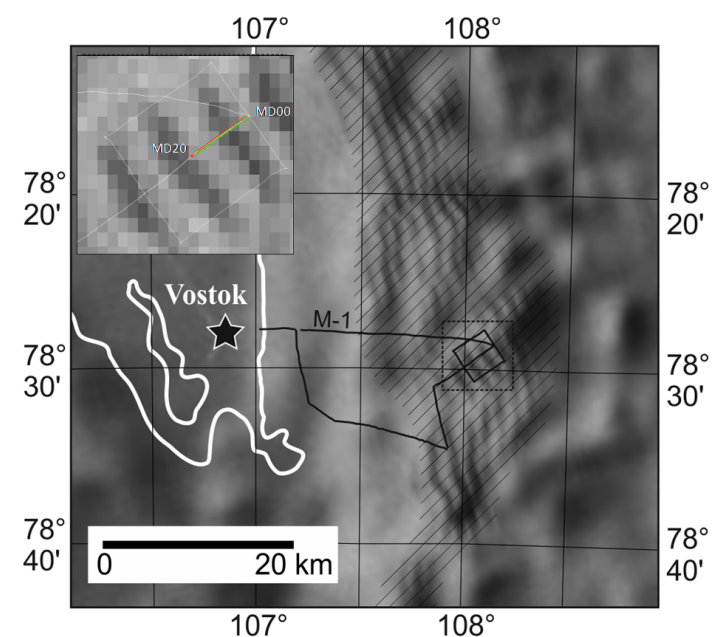

Figure 1. Vicinity of Vostok Station and the location of the study area. The megadunes are highlighted by hatching. Black line is the route of GPR and geodetic profiles. The location of the glaciological profile is shown in the insert (MD00-MD20). White line is the Vostok lake shoreline adapted from Popov and Masolov (2007).

2015). The snow samples were taken again for chemical and isotopic analyses.

In January 2015 we also drilled a $20 \mathrm{~m}$ borehole in point MD00 (Fig. 1). In the obtained firn core we measured snow density and took samples for stable water isotope analysis with a resolution of $10 \mathrm{~cm}$.

The concentration of heavy water isotopes $\left(\delta D\right.$ and $\left.\delta^{18} \mathrm{O}\right)$ in 42 surface-snow samples taken in 58th and 59th RAE, as well as in 183 samples from the MD00 core, were measured at the Climate and Environmental Research Laboratory (CERL) using a Picarro L2120- $i$ analyser. Our working standard (VOS), measured after every five samples, was made of the light Vostok snow and calibrated against the International Atomic Energy Agency (IAEA) standards VSMOW-2, GISP and SLAP-2. The reproducibility of results defined by remeasurements of randomly chosen samples was $0.04 \%$ for $\delta^{18} \mathrm{O}$ and $0.2 \%$ for $\delta D$, which is 2 orders of magnitude less than the natural variability of the snow isotopic composition (see below) and thus satisfactory for the purposes of the study.

In October 2015 we also measured ${ }^{17} \mathrm{O}$-excess values in the samples collected during the 59th RAE using a Picarro L2140-i analyzer. For this, each sample was measured 15 times in the high-precision mode and we took an average of the last 10 measurements. For every three samples we measured the VOS standard previously calibrated against VSMOW-2, GISP and SLAP-2 (taking into account that they have ${ }^{17} \mathrm{O}$-excess values of, correspondingly, 0,22 and 0 per meg; Schoenemann et al., 2013). The ${ }^{17} \mathrm{O}$-excess value of VOS was found to be 0 per meg, similar to SLAP. The reproducibility of the ${ }^{17} \mathrm{O}$-excess values of individual samples was 8 per meg.
All the data discussed in this paper are presented in Table 1 .

\subsection{GNSS positioning}

The absolute altitude and location were determined with high accuracy along the profile using the geodetic GPS technique.

Therefore the Bernese GPS Software 5.1 (Dach et al., 2007) was used to process the two kinematic GNSS profiles (K58B and K58C) as a combined differential solution from the GPS and GLONASS observations. As reference stations for this network solution, we used two local receivers at Vostok station at a distance of $30 \mathrm{~km}$ and two additional reference stations at the coast with baseline lengths of about $1350 \mathrm{~km}$ (near the Russian research stations Progress and a station of the global IGS-network near the Australian Station Casey). After reducing the antenna positions to the snow surface we estimated the accuracy by calculating the height differences at track crossovers. Crossovers inside one track imply an internal RMS with differences of $2.9 \mathrm{~cm}$ (at 160 crossover points) for track K58B and $2.4 \mathrm{~cm}$ (at 9 crossover points) for track K58C. With a RMS of $7.7 \mathrm{~cm}$ at 5159 crossovers between the two tracks, we can estimate the absolute precision of a single kinematic surface height according to the variance propagation to about $5.4 \mathrm{~cm}$.

\subsection{GPR data}

During the austral summer field season of the 58th Russian Antarctic Expedition (January 2013), the ground penetrating radar (GPR) profiling was performed to study the snow-firn layer structure of the megadune area. The $200 \mathrm{MHz}$ GSSI SIR10B GPR with $5106200 \mathrm{MHz}$ antenna was applied.

The GPR equipment was installed on two sledges towed by a Ski-Doo. The route of the GPR profiling was the same with the geodetic observations. In total, about $80 \mathrm{~km}$ of the GPR profiles were obtained (Fig. 1), though in this paper we only use the $2 \mathrm{~km}$ section obtained along the glaciological profile (points MD00-MD20 in Fig. 1).

The main problem with the processing and interpretation of the GPR data is the dielectric properties of the media where the electromagnetic waves propagate. We used the model published in Popov and Eberlein (2014) to transform the radio-echo time section (Fig. 2) into the depth section. To calculate the vertical electromagnetic wave speed, we used the firn density data measured in the MD00 core.

In Fig. 2 we show the GPR registration recorded along the glaciological profile (MD00-MD20).

\section{Results}

The megadune formation is related to a sharp increase of the ice sheet slope in the prevailing wind direction (SPWD) (Frezzotti et al., 2002b). The Vostok megadunes are not 


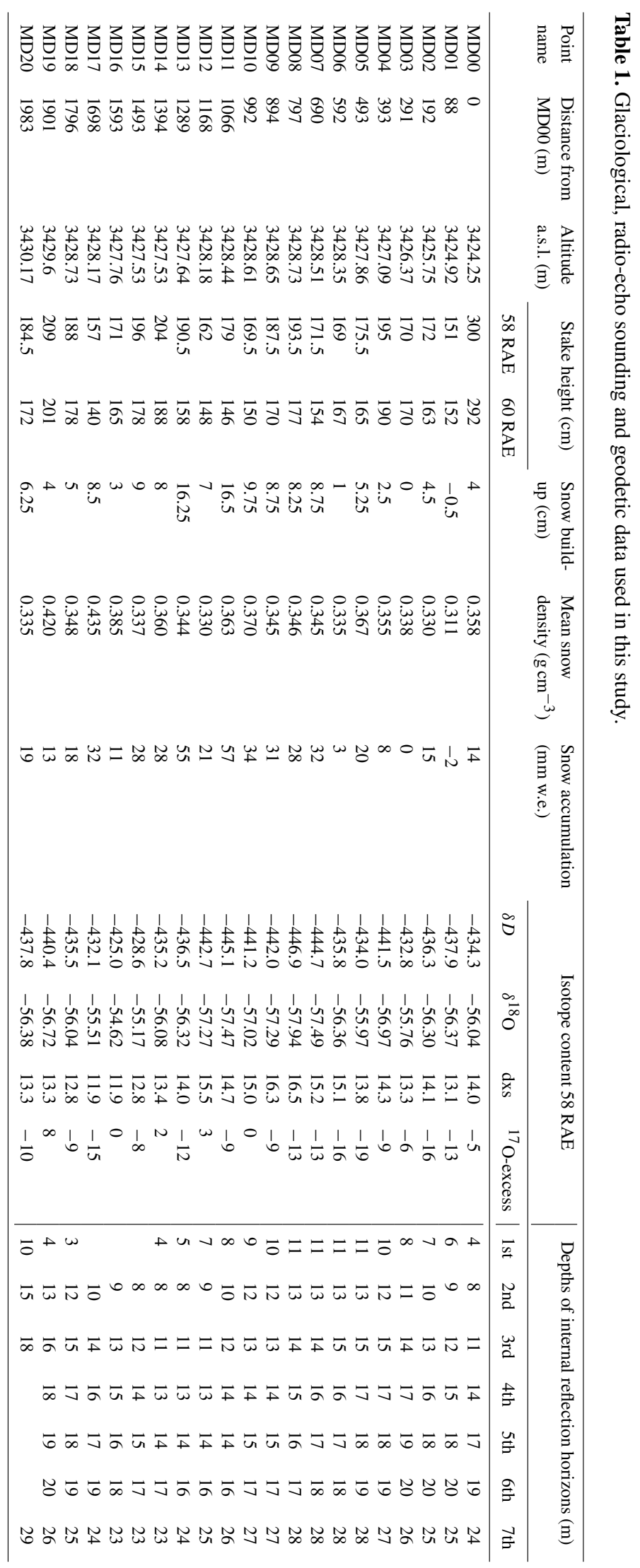




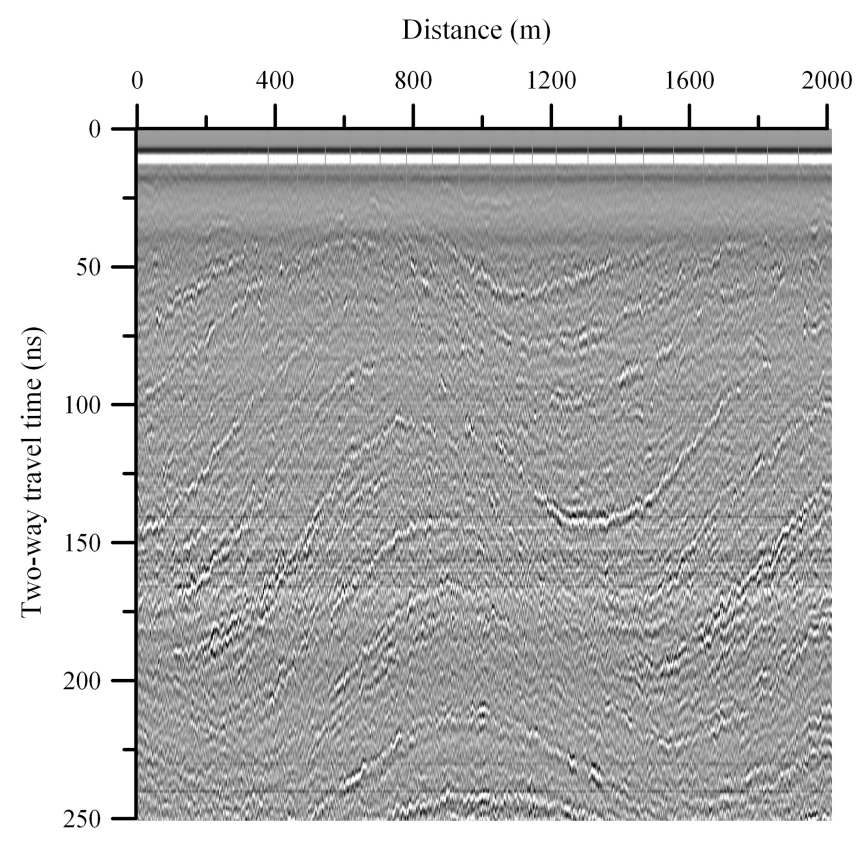

Figure 2. GPR registration recorded along the MD00 profile.

an exception, as they form leeward from the eastern shore of Lake Vostok, where the SPWD changes from near zero or even negative values (interestingly, in the near vicinity of Vostok Station the wind is blowing uphill) to about $1.6 \mathrm{~m} \mathrm{~km}^{-1}$. The latter figure generally agrees with the Frezzotti et al. (2002) conclusion that the megadunes only develop where the SPWD is from 1 to $1.5 \mathrm{~m} \mathrm{~km}^{-1}$.

The wavelength of the Vostok megadunes is about $1.9 \mathrm{~km}$, and the amplitude (the elevation change between the dune crest and the nearest windward hollow) is about $1.2 \mathrm{~m}$, i.e. they are relatively small compared to those reported in the above-mentioned studies.

Below we present the results of the glaciological investigations in the Vostok megadune area (Fig. 3).

\subsection{Accumulation rate and isotopic content of snow in megadunes}

Due to the subsequent measurements of the heights of the stakes established across the megadunes, we were able to define the snow accumulation between January 2013 and January 2015 (Fig. 3e). One may clearly see the regular spatial variability of the snow build-up. In accordance with the previous studies (see the review in Introduction), the snow is removed from locations with the increased surface slope (leeward side of the dunes) and deposited where the slope is decreased or inversed (hollow between dunes and windward side of the dunes). In a distance of few hundred metres the accumulation changes by an order of magnitude, from -0.5 to $16 \mathrm{~cm}$ of snow (or from -0.2 to $58 \mathrm{~mm}$ w.e. according to the surface-snow density, Fig. 3d). This range is larger than that reported by Frezzotti et al. (2002b) (from 7 to $35 \mathrm{~mm}$ ). The mean annual accumulation over one dune wavelength is $22 \mathrm{~mm}$, which is very similar to the accumulation at the Vostok stake network $(23 \mathrm{~mm})$. If the precipitation rates at Vostok station and in the megadune area were the same, then our result does not support the observation that over the megadune areas the accumulation is reduced due to the wind-driven sublimation (Frezzotti et al., 2004).

Snow accumulation variability observed at the stakes during only two years of observations may not adequately represent the long-term average due to a very large random component. We used the GPR data (Fig. 3g) and data on firn density from the $20 \mathrm{~m}$ core in order to evaluate spatial variability of the multi-year average of the snow accumulation rate. The first internal reflection horizon (estimated age is about 130 years, see below) is located at the depth that varies from 3 to $11 \mathrm{~m}$. Thus, the mean 130-year snow accumulation rate varies between 1 and $35 \mathrm{~mm}$ w.e. over one full dune wavelength, with an average of $21 \mathrm{~mm}$ w.e. Thus, the multi-year spatial variability of snow accumulation rate is considerably smaller than that obtained from 2-year stake measurements, but still larger than that reported by Frezzotti et al. (2002b).

The surface-snow density does not show any distinct spatial variability (Fig. 3d). The mean snow density $\left(0.355 \mathrm{~g} \mathrm{~cm}^{-3}\right)$ is slightly higher than that measured at Vostok stake network $\left(0.33 \mathrm{~g} \mathrm{~cm}^{-3}\right)$.

During the fieldwork seasons we also did not observe big differences between snow surface character in leeward and windward slopes of the dunes (Fig. 4). The erosion zone does not demonstrate the dominance of the glaze surface, and no big sastrugi are observed in the accumulation zone, as reported by Frezzotti et al. (2002b) for the Victoria Land megadune field. The small difference in snow morphology between low- and high-accumulation zones of the dune may be related to the relatively small dune size, although it does not explain rather big spatial variability of snow accumulation.

The spatial variability of the accumulation rate covaries well with the surface slope: the smaller the slope, the higher the accumulation (Fig. 3f and e).

In Fig. 3a-c we show the isotopic composition $(\delta D$, $\mathrm{dxs}$ and ${ }^{17} \mathrm{O}$-excess) of the upper $1.5 \mathrm{~m}$ of snow sampled twice near each point of our profile. One can see a wave in snow isotopic content $(\delta D)$ with a magnitude of about $25 \%$ and a wavelength similar to that of the megadune. The spatial variability of the snow isotopic composition in the megadune area is significantly larger than in the area outside the megadunes. For example, the standard deviation of the $\delta D$ values in the samples representing the upper $1.5 \mathrm{~m}$ of snow and taken along a $40 \mathrm{~km}$ profile in the southern part of Lake Vostok, where the glacier is characterized by a flat surface, is $\pm 4 \%$ o (Ekaykin et al., 2012) against $\pm 6 \%$ o in the megadune area. Another difference is that outside the megadunes the variability of snow isotopic composition is 


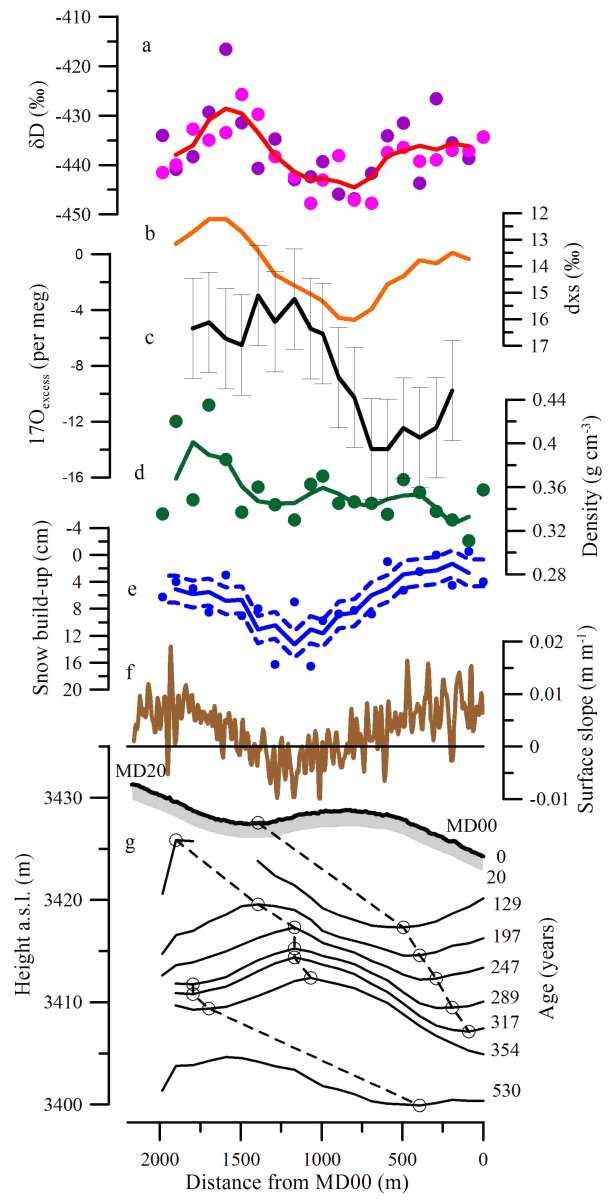

Figure 3. The results of the glaciological, GPR and geodetic survey in the Vostok megadune area. (a-c) Isotopic content of the surface $(1.5 \mathrm{~m})$ layer of the snow thickness: (a) $\delta D$, (b) dxs and (c) ${ }^{17} \mathrm{O}-$ excess. For $\delta D$ the points show the individual samples and the red line is the average of the 58 and 59 RAE samples. For dxs only the average is shown. Note that the dxs axis is reversed. For ${ }^{17} \mathrm{O}-$ excess we showed the 5-point running means with the error bars ( $\pm 1 \sigma$, where $\sigma$ is the error of the average of five individual values). (d) Surface $(20 \mathrm{~cm})$ snow density, individual values (points) and 3point running mean (line). (e) Mean snow build-up in 2013-2014, individual values (points) and 3-point running mean. Dashed lines show the confidence interval $( \pm 1 \sigma)$ of 2-year average accumulation value as deduced from Vostok stake network. Note that the $y$ axis is reversed. (f) Surface slope calculated over $20 \mathrm{~m}$ intervals of the ice sheet surface. Negative values mean that the local slope is the opposite of the general slope in this region (from south-west to northeast). (g) The elevation of the ice sheet surface and seven internal reflection horizons (IRH) above sea level defined by the geodetic measurements and GPR survey. The grey shading depicts the snow layer $(1.5 \mathrm{~m})$ in which the snow isotopic content was measured. The dashed lines connect the fold hinges used to calculate the dune drift velocity. The values to the right are the estimated ages of each IRH relative to January 2015. The profile is spread from the south-west (left part of the figure) to the north-east (right part), see Figure 1. The individual values shown in Fig. 3 can be found in Table 1.

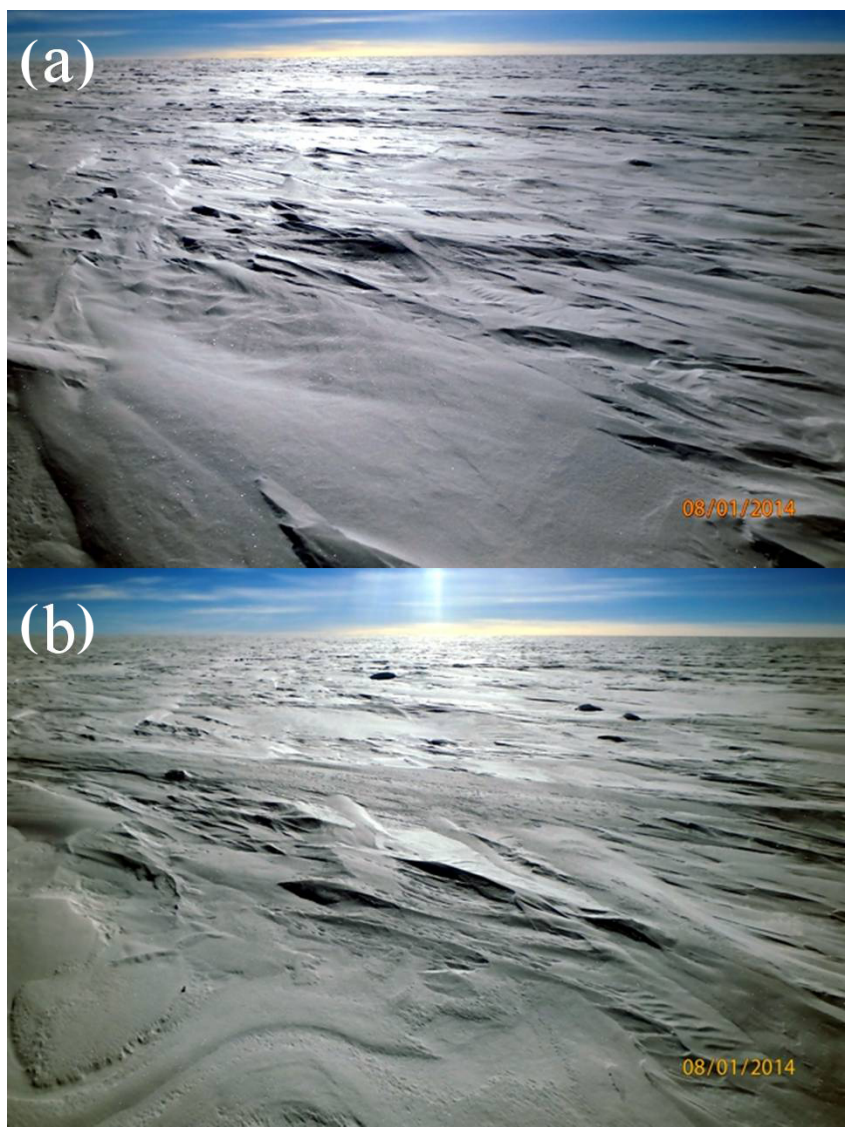

Figure 4. Photo of the snow surface in points MD02: (a) erosion zone, leeward slope of the dune and (b) MD13 deposition zone, the hollow between dunes.

random, with no clear periodicity. At the same time, the average values of $\delta D$ are similar in both cases, around $-440 \%$.

There is a negative covariation between snow isotopic composition and accumulation rate (correlation coefficient, -0.38 , is not statistically significant due to the small number of points).

We explain this behaviour of the snow isotopic composition by different post-depositional alteration of the initial isotopic composition of snow precipitation deposited in the low- and high-accumulation zones of the megadunes. Indeed, the erosion zone is characterized by "a long, multiannual, steep temperature-gradient metamorphism" (Frezzotti et al., $2002 b), p .8$. Thus, the snow here should be enriched in heavy isotopes due to strong post-depositional modification (Town et al., 2008) that may be further facilitated by the increased permeability of the snow in such locations (Albert et al., 2004). We may speculate that in the megadunes described by Frezzotti et al. (2002b), characterized by a very strong modification of the snow physical properties, the isotopic transformation should be even stronger than in the Vostok dunes.

An alternative explanation of the negative spatial relationship between isotopic composition and snow accumulation 
was suggested by Ekaykin et al. (2002). Since in winter the snow crystals are smaller and wind speed is higher, this snow could be more easily redistributed by wind comparing to snow precipitated in summer. If so, in the erosion zone of the megadunes the proportion of summer snow is larger than in the accumulation zone.

We may use the isotopic data to determine which mechanism, post-depositional, redistributional or both, is mainly responsible for the anomaly of the snow isotopic composition in the megadune area.

The observed $\mathrm{dxs} / \delta D$ and ${ }^{17} \mathrm{O}$-excess $/ \delta D$ slopes (ratios between the standard deviations of the smoothed profiles shown in Fig. 3a, b and c) are correspondingly $-0.2 \% \%_{0}^{-1}$ and 0.9 per meg $\% o^{-1}$. During the postdepositional changes of the snow isotopic composition, these slopes are $-0.2 \% \circ \% 0^{-1}$ and 0.4 per meg $\%^{-1}$ (Ekaykin et al., 2016). During the seasonal cycle of the isotopic composition of snow precipitation at Vostok, these parameters are related by slopes $-0.1 \% \%^{-1}$ and 0.4 per meg $\% o^{-1}$ (Landais et al., 2012).

Thus we may conclude that the mixing of the summer and winter precipitation in different proportions cannot explain the variability of snow isotopic composition observed in the megadune area, since the variability of ${ }^{17} \mathrm{O}$-excess and of $d x s$ in this case would be significantly smaller. The postdepositional factor would better explain the observed snow isotopic composition in the megadunes, but the variability of ${ }^{17} \mathrm{O}$-excess still seems to be too strong. Note, however, that the data by Ekaykin et al. (2016) were obtained in laboratory experiments, not in natural conditions, so the ${ }^{17} \mathrm{O}-$ excess $/ \delta D$ slopes reported there may be underestimated.

We should also note that the ${ }^{17} \mathrm{O}$-excess values positively covariate with the accumulation rate (Fig. $3 \mathrm{c}$ and e), although one would expect a negative covariation if the snow isotopic composition variability is due to the post-depositional processes. At present we do not know whether this positive covariation is caused by errors in the ${ }^{17} \mathrm{O}$-excess values, or if it suggests another mechanism that creates isotopic anomalies in the megadune area.

\subsection{Megadune drift}

We used the GPR data to reconstruct the previous positions of the dunes and calculate the velocity of the dune drift.

In the GPR profile taken across the megadunes (Fig. 2), we see several distinct internal reflection horizons (IRH). For seven of them we defined the depths (Table 1) and, subtracting these depths from the ice sheet elevation, we could define the absolute altitude of each IRH (Fig. 3g). Thus we can see the buried surfaces of our dune and may trace its drift in time.

For this, we first need to date each IRH. We used the density profile obtained from the MD00 core and the average snow accumulation rate in the megadune area in order to calculate the depth-age function and determine the age of each
IRH (Fig. 3g). The uppermost IRH marks the surface of the dune about 130 years ago and the lowermost 530 years ago.

We chose three fold hinges (the summit of crests and two lowest points of the fold dips) to trace the dune drift. On average, the dune drifts upwind at a rate of $4.6 \pm 1.1 \mathrm{~m} \mathrm{yr}^{-1}$. This corresponds very well with the value reported by Frezzotti et al. (2002b), $5 \mathrm{~m} \mathrm{yr}^{-1}$. With this velocity, a dune drifts by one full wavelength in about 410 years.

As pointed by Arcone et al. (2005), the apparent dune drift velocity observed in the GPR images is a combination of the real dune velocity and the ice movement, and the real dune velocity is higher than the observed one. According to (Richter et al., 2013), ice flow velocities in this region do not exceed $2 \mathrm{~m} \mathrm{yr}^{-1}$, so the real dune drift velocity could be up to $6.6 \mathrm{~m} \mathrm{yr}^{-1}$. However, the ice is moving almost in parallel with the dune crests (from north-west to south-east). So, the projection of the ice speed vector on the MD profile is close to $0 \mathrm{~m} \mathrm{yr}^{-1}$, and the correction to the dune drift velocity due to the ice movement should be close to zero, too. Finally, for the purposes of our study we need not real, but the resultant dune velocity observed by GPR, so in the further calculations we use the apparent dune velocity of $4.6 \mathrm{~m} \mathrm{yr}^{-1}$.

\subsection{Non-climatic temporal oscillation related to the megadune drift}

When the dune drifts, the spatial anomalies in snow physical properties, accumulation rate and isotopic composition drift accordingly. For example, the point MD00, now located at the leeward side of the dune with reduced accumulation and enriched isotopic composition, was in the hollow between dunes with increased accumulation and lower heavy isotope content about 300 years ago. If one drills an ice core in the megadune area, he would see a quasi-periodic (with the period of 410 years) oscillations in snow accumulation and isotopic composition related to the dune drift.

Let us simulate an oscillation such as we would see in a core drilled at the MD00 point.

In Fig. 5a we showed a temporal variability of snow accumulation (blue) and isotopic composition (red) that should be seen in point MD00 when the dune crosses it. To construct these curves, we simply divided the distance of each point in Fig. 3a and e by the above-mentioned velocity of the dune drift. We also showed the climatic variability in the Vostok region over the same time interval (Ekaykin et al., 2014) in Fig. 5a in purple. Note that the amplitudes of the both components are similar.

Combining the dune-related and climatic components, we obtain the expected temporal variability of snow isotopic composition in MD00 (Fig. 5b). Then we transform it to a vertical isotopic profile using the depth-age function presented in Fig. 5c. This function takes into account the significant dune-related variability in snow accumulation rate (Fig. 5a), which is why it is essentially non-linear. The resulting simulated vertical isotopic profile is presented in Fig. 5d 

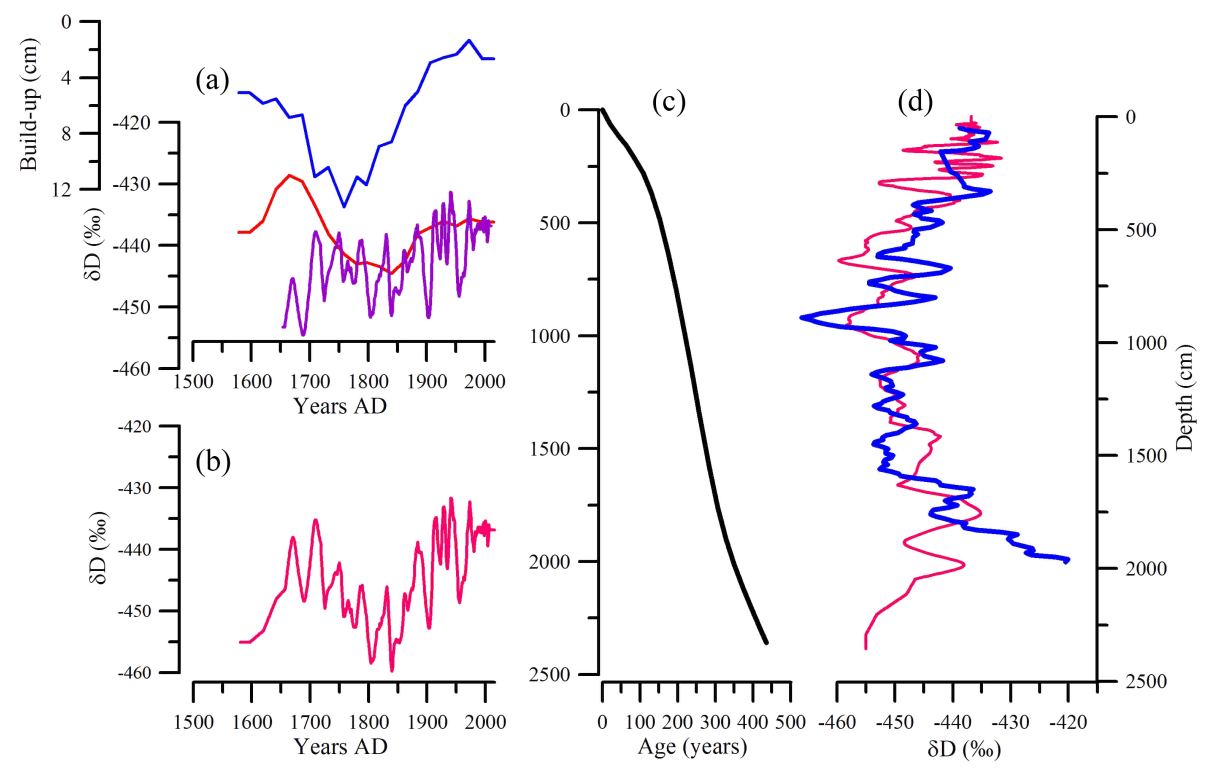

Figure 5. Simulated isotope profile in MD00 point. (a) The values of snow accumulation rate (blue) and isotopic composition (red) that could be observed in point MD00 if one measured them for as long as the dune travel across this point. To calculate this we used the data from Fig. 3a and e and data on the dune drift velocity. Purple shows climatic variability of the snow isotopic composition in the Vostok region taken from (Ekaykin et al., 2014). (b) A combination of climatic and dune-related isotopic variability (red and purple from Fig. (a)). (c) Depth-age function for the snow thickness in point MD00. (d) Simulated vertical profile of snow isotopic composition calculated using the data from (b) and depth-age function (c), in red, compared with the real vertical profile of snow isotopic composition measured in the core drilled in point MD00, in blue.

by a red line. In the upper part of the profile the isotopic oscillations are compressed due to the low accumulation rate, and when the accumulation is higher, they are stretched.

In our simulations we do not take into account that the megadune snow may experience enhanced diffusive smoothing due to the increased ventilation of the snow column. In this case the isotopic profile could be substantially smoothed.

In Fig. 5d we also showed the real isotopic profile from the MD00 core with the blue line. One can see a good resemblance between them, except for the very bottom part of the MD00 core. Indeed, at a depth of $20 \mathrm{~m}$ the core has a $\delta D$ isotopic composition of $-420 \%$. Neither the climatic record nor the isotopic profile from the megadunes (Fig. 5a) demonstrate such high isotopic value, which is why we could not reproduce it in our simulations.

\section{Discussion - non-climatic variability in ice cores}

In the previous sections we demonstrated that the snow isotopic composition has significant spatial variability in the megadune area, suggested a possible mechanism to explain this variability and explained how this "dune-related" signal is transferred to a firn core isotopic profile. We calculated an artificial firn core isotopic profile in the megadune area and compared it with the real firn core isotopic profile.

In the case of MD00 core we know that the signal we see is mostly related to a dune drift, but how can one separate the climatic signal from non-climatic variability in real ice cores?

Indeed, it is commonly understood that a megadune area is an unsuitable place to drill ice for climatic studies, but it does not mean that the locations outside the megadune fields are free from non-climatic, relief-related variability.

For example, we may mention the South Pole station region, which is not a megadune area, but a detailed topographic survey shows megadune-like features with a typical amplitude of few metres and wavelength of several kilometres - see Fig. 8 in (Van der Veen et al., 1999) and Fig. 2 in (Hamilton, 2004). Unlike the megadunes, these snow hills are not elongated, but rather round in shape. The authors suggest these structures are not stationary, but slowly change their locations, which causes temporal non-climatic variability of snow accumulation rate with the period of several hundred or a few thousand years. Very similar structures are observed around the Kohnen Station (Eisen et al., 2005) and in West Antarctica (Arcone et al., 2005).

Even the vicinity of the main domes cannot be considered to be "dune-safe". Indeed, the study of the snow isotopic composition profile in two neighbouring cores drilled about $55 \mathrm{~km}$ to the north-east from the summit of Dome $\mathrm{C}$ showed a very low signal-to-noise ratio, likely related to the local ice sheet topography (Benoist et al., 1982).

In Dronning Maud Land the ice cores drilled at relatively short distances from one another demonstrate opposite 
trends in the snow accumulation rates over the past 200 years (Oerter et al., 2000), which may be considered to be an influence of the non-climatic factors.

In general, signal-to-noise ratio of both snow accumulation rate and isotopic composition is very small in lowaccumulation sites, being in the order of 0.2 (Ekaykin et al., 2014). The noise, related to the snow redistribution by wind and/or post-depositional processes, is larger than the climatic signal even at the centennial scale. This means that when studying climatic variability within a period of less than $10^{3}-$ $10^{4}$ years in the low accumulation area (which comprises most of the East Antarctica; Arthern et al., 2006), more than one ice core should be investigated for each location.

The influence of snow topography on snow accumulation is known and to a large extent understood on the spatial scale from $10^{-2}$ to $10^{1} \mathrm{~m}$ (micro-relief) and from $10^{3}$ to $10^{6} \mathrm{~m}$ (megadunes and continental scale). However, very little is known about the scale from $10^{1}$ to $10^{3} \mathrm{~m}$; the range of "mesodunes" (Ekaykin et al., 2002; Eisen et al., 2008). Mesodunes are relatively small forms (with typical wavelengths from 200 to $300 \mathrm{~m}$ ) of snow relief observed in the vicinity of Vostok Station. It was shown that the mesodunes cause a spatial variability of snow properties: on the bumps the snow accumulation is lower and its isotopic composition is higher, while in the hollows between the dunes more snow accumulates with lower concentration of heavy isotopologues (Ekaykin et al., 2002). Since these dunes seem to not be stagnant, it is likely that the drift of the mesodunes causes the non-climatic temporal oscillations of snow isotopic composition and accumulation rate with a period of a few decades due to mechanisms similar to those described in this paper for the megadunes. Further studies of this phenomenon are needed.

\section{Conclusion}

The ice cores are a priceless source of numerous and diverse palaeo-climatic data, and this will hold true even despite the unavoidable limitations. One of the most important limitations is related to a high level of noise which contaminates the climatic signal on relatively short timescales (years to millennia), especially in the low-accumulation areas. The main reason for this noise is a complex snow/ice sheet topography that leads to snow redistribution due to wind activity, which is further complicated by post-depositional processes.

In this paper we present the results of the fieldwork carried out during three Antarctic summer seasons in the vicinity of Vostok Station. We mainly deal with the influence of large snow relief forms, megadunes, on the snow isotopic composition. We demonstrate that the leeward sides of the dunes are characterized by reduced accumulation and increased concentration of heavy water molecules, likely due to post-depositional alteration of the snow isotopic content.
In contrast, windward sides of the dunes accumulate more snow that is enriched by light water isotopes.

Using the GPR data, we were able to trace the drift of the dunes and calculate their velocity, $4.6 \pm 1.1 \mathrm{~m} \mathrm{yr}^{-1}$. This allowed us to simulate the temporal variability of the snow isotopic composition that would be observed at a given point due to the passing of the megadune across this point. Then we compared this artificial vertical profile of the snow isotopic composition with the real isotopic data from a firn core drilled in the megadune site. We showed that the two profiles are very similar.

As a result of our study we come to the following conclusions:

1. For the first time we demonstrated that snow isotopic composition has significant spatial variability in the megadune area in covariance with the snow accumulation rate and surface slope, although the mechanism that forms this variability is yet to be clarified. We also demonstrated how these spatial waves are transformed into the oscillations of snow isotopic composition in a firn/ice core vertical profile.

2. Based on published data we may conclude that significant (periodic or non-periodic) spatial variability is widespread in Antarctica, even outside the megadune areas. The drift of different types of dunes across the snow/ice sheet surface causes non-climatic temporal variability of snow accumulation rate and isotopic composition, as observed in firn or ice cores, thus considerably reducing the signal-to-noise ratio on timescales from decades to millennia.

3. The only robust way to obtain a reliable climatic signal is to investigate several ice cores and to construct a stack record of studied parameters.

We also suggest that the megadunes are a unique environment that provides the necessary conditions to test different hypotheses. For example, in a short distance one can find completely different locations in terms of snow accumulation rate, isotopic composition, physical and (likely) chemical properties, which could be used to study the postdepositional processes in order to model glacial conditions (Severinghaus et al., 2010) etc.

In the future we plan to investigate the spatial variability of chemical content and the concentration of microparticles and other compounds in the surface snow of the Vostok megadune area.

Acknowledgements. We thank O. Eisen, M. Frezzotti, T. Scambos and M. Schneebeli for numerous corrections and suggestions that allowed us to improve significantly the manuscript.

The logistic operations in Antarctica were provided by the Russian Antarctic Expedition. We personally thank Vitaly Zarovchatskiy for his help in the fieldwork. The authors are grateful 
to Anna Kozachek and Diana Vladimirova (CERL) for the highquality isotopic data. We also thank Achille Zirizzotti and Stefano Urbini (Istituto Nazionale di Geofisica e Vulcanologia, Rome, Italy) for providing the GPR equipment.

This study was completed at the expense of the grant of the Russian Science Foundation (project 14-27-00030).

Edited by: O. Eisen

\section{References}

Alberti, M. and Biscaro, D.: Height variation detection in polar regions from ICESat satellite altimetry, Comput. Geosci., 36, 1-9, 2010.

Albert, M., Shuman, C., Courville, Z., Bauer, R., Fahnestock, M., and Scambos, T.: Extreme firn metamorphism: Impact of decades of vapor transport on near-surface firn at a low-accumulation glazed site on the East Antarctic plateau, Ann. Glaciol., 39, 7378, 2004.

Anschütz, H., Eisen, O., Rack, W., and Scheinert, M.: Periodic surface features in coastal East Antarctica, Geophys. Res. Lett., 33, $1-5,2006$.

Anschütz, H., Eisen, O., Oerter, H., Steinhage, D., and Scheinert, M.: Investigating small-scale variations of the recent accumulation rate in coastal Dronning Maud Land, East Antarctica, Ann. Glaciol., 46, 14-21, 2007.

Arcone, S. A., Spikes, V. B., and Hamilton, G. S.: Stratigraphic variation within polar firn caused by differential accumulation and ice flow: Interpretation of a $400 \mathrm{MHz}$ short-pulse radar profile from West Antarctica, J. Glaciol., 51, 407-422, 2005.

Arthern, R. J., Winebrenner, D. P., and Vaughan, D. G.: Antarctic snow accumulation mapped using polarization of $4.3-\mathrm{cm}$ wavelength microwave emission, J. Geophys. Res., 111, D06107, doi:10.1029/2004JD005667, 2006.

Benoist, J. P., Jouzel, J., Lorius, C., Merlivat, L., and Pourchet, M.: Isotope climatic record over the last $2.5 \mathrm{ka}$ from Dome C, Antarctica, ice cores, Ann. Glaciol., 3, 17-22, 1982.

Bintanja, R. and Reijmer, C. H.: A simple parameterization for snowdrift sublimation over Antarctic snow surfaces, J. Geophys. Res., 106, 31739-31748, 2001.

Black, H. P. and Budd, W.: Accumulation in the region of Wilkes, Wilkes Land, Antarctica, J. Glaciol., 5, 3-15, 1964.

Courville, Z. R., Albert, M. R., Fahnestock, M. A., Cathles IV, L. M., and Shuman, C. A.: Impacts of an accumulation hiatus on the physical properties of firn at a low-accumulation polar site, J. Geophys. Res., 112, 1-11, 2007.

Dach, R., Hugentobler, U., Fridez, P., and Meindl, M.: Bernese GPS software version 5.0, Univ. of Bern, Bern, Switzerland, 2007.

Dadic, R., Mott, R., Horgan, H. J., and Lehning, M.: Observations, theory, and modeling of the differential accumulation of Antarctic megadunes, J. Geophys. Res.-Earth Surf., 118, 2343-2353, doi:10.1002/2013JF002844, 2013.

Das, I., Bell, R. E., Scambos, T. A., Wolovick, M., Creyts, T. T., Studinger, M., Frearson, N., Nicolas, J. P., Lenaerts, J. T. M., and Van den Broeke, M. R.: Influence of persistent wind scour on the surface mass balance of Antarctica, Nat. Geosci., 6, 367-371, 2013.
Dixon, D. A., Mayewski, P. A., Korotkikh, E., Sneed, S. B., Handley, M. J., Introne, D. S., and Scambos, T. A.: Variations in snow and firn chemistry along US ITASE traverses and the effect of surface glazing, The Cryosphere, 7, 515-535, doi:10.5194/tc-7515-2013, 2013.

Dolgushin, L. D.: Geographical observations in Antarctica. Rep. 1, Izv. AN SSSR, Geography, 28-47, 1958.

Dreyfus, G., Jouzel, J., Bender, M., Landais, A., Masson- Delmotte, V., and Leuenberger, M.: Firn processes and $\delta^{15} \mathrm{~N}$ : Potential for a gas-phase climate proxy, Quaternary Sci. Rev., 29, 28-42, 2010.

Eisen, O., Rack, W., Nixdorf, U., and Wilhelms, F.: Characteristics of accumulation around the EPICA deep-drilling site in Dronning Maud Land, Antarctica, Ann. Glaciol., 41, 41-46, 2005.

Eisen, O., Frezzotti, M., Genthon, C., Isaksson, E., Magand, O., Van den Broeke, M. R., Dixon, D. A., Ekaykin, A. A., Holmlund, P., Kameda, T., Karlöf, L., Kaspari, S., Lipenkov, V. Y., Oerter, H., Takahashi, S., and Vaughan, D. G.: Ground-based measurements of spatial and temporal variability of snow accumulation in East Antarctica, Rev. Geophys., 46, 1-39, 2008.

Ekaykin, A. A., Lipenkov, V. Y., Barkov, N. I., Petit, J. R., and Masson-Delmotte, V.: Spatial and temporal variability in isotope composition of recent snow in the vicinity of Vostok Station: Implications for ice-core interpretation, Ann. Glaciol., 35, 181-186, 2002.

Ekaykin, A. A., Lipenkov, V. Y., and Shibaev, Y. A.: Spatial distribution of the snow accumulation rate along the ice flow lines between Ridge B and Lake Vostok, Led i Sneg, 122-128, 2012.

Ekaykin, A. A., Kozachek, A. V., Lipenkov, V. Y., and Shibaev, Y. A.: Multiple climate shifts in the Southern Hemisphere over the past three centuries based on central Antarctic snow pits and core studies, Ann. Glaciol., 55, 259-266, 2014.

Ekaykin, A. A., Hondoh, T., Lipenkov, V. Y., Miyamoto, A., and Barkan, E.: Laboratory measurements of the impact of sublimation on post-depositional changes in snow isotope content, 2nd IPICS Open Science Conference, Hobart, p. 204, 2016.

Fahnestock, M. A., Scambos, T. A., Shuman, C. A., Arthern, R. J., Winebrenner, D. P., and Kwok, R.: Snow megadune fields on the East Antarctic plateau: Extreme atmosphere-ice interaction, Geophys. Res. Lett., 27, 3719-3722, 2000.

Frezzotti, M., Gandolfi, S., La Marca, F., and Urbini, S.: Snow dunes and glazed surfaces in Antarctica: New field and remotesensing date, Ann. Glaciol., 81-87, 2002a.

Frezzotti, M., Gandolfi, S., and Urbini, S.: Snow megadunes in Antarctica: Sedimentary structure and genesis, J. Geophys. Res., 107, 1-12, doi:10.1029/2001JD000673, 2002 b.

Frezzotti, M., Pourchet , M., Flora, O., Gandolfi, S., Gay, M., Urbini, S., Vincent, C., Becagli, S., Gragnani, R., Proposito, M., Severi, M., Traversi, R., Udisti, R., and Fily, M.: New estimations of precipitation and surface sublimation in East Antarctica from snow accumulation measurements, Clim. Dynam., 23, 803-813, 2004.

Frezzotti, M., Urbini, S., Proposito, M., Scarchilli, C., and Gandolfi, S.: Spatial and temporal variability of surface mass balance near Talos Dome, East Antarctica, J. Geophys. Res., 112, 1-15, 2007.

Fujita, S., Maeno, H., Furukawa, T., and Matsuoka, K.: Scattering of VHF radio waves from within the top $700 \mathrm{~m}$ of the Antarctic ice sheet and its relation to the depositional environment: A case-study along the Syowa-Mizuho-Dome Fuji traverse, Ann. Glaciol., 157-164, 2002. 
Fujita, S., Holmlund, P., Andersson, I., Brown, I., Enomoto, H., Fujii, Y., Fujita, K., Fukui, K., Furukawa, T., Hansson, M., Hara, K., Hoshina, Y., Igarashi, M., Iizuka, Y., Imura, S., Ingvander, S., Karlin, T., Motoyama, H., Nakazawa, F., Oerter, H., Sjöberg, L. E., Sugiyama, S., Surdyk, S., Ström, J., Uemura, R., and Wilhelms, F.: Spatial and temporal variability of snow accumulation rate on the East Antarctic ice divide between Dome Fuji and EPICA DML, The Cryosphere, 5, 1057-1081, doi:10.5194/tc-51057-2011, 2011.

Goodwin, I. D.: Snow accumulation and surface topography in the katabatic zone of eastern Wilkes Land, Antarctica, Antarct. Sci., 2, 235-242, 1990.

Gow, A. J. and Rowland, R.: On the relationship of snow accumulation to surface topography at "Byrd Station", Antarctica, J. Glaciol., 5, 843-847, 1965.

Gregory, S. A., Albert, M., and Baker, I.: Impact of physical properties and accumulation rate on pore close-off in layered firn, The Cryosphere, 8, 91-105, doi:10.5194/tc-8-91-2014, 2014.

Hamilton, G. S.: Topographic control of regional accumulation rate variability at South Pole and implications for ice-core interpretation, Ann. Glaciol., 39, 214-218, 2004.

Karlöf, L., Winebrenner, D. P., and Percival, D. B.: How representative is a time series derived from a firn core? A study at a lowaccumulation site on the Antarctic plateau, J. Geophys. Res., 111, 1-11, 2006.

Kaspari, S., Mayewski, P. A., Dixon, D. A., Spikes, V. B., Sneed, S. B., Handley, M. J., and Hamilton, G. S.: Climate variability in West Antarctica derived from annual accumulatiuon-rate records from ITASE firn/ice cores, Ann. Glaciol., 39, 585-594, 2004.

Landais, A., Ekaykin, A. A., Barkan, E., Winkler, R., and Luz, B.: Seasonal variations of ${ }^{17} \mathrm{O}$-excess and d-excess in snow precipitation at Vostok Station, East Antarctica, J. Glaciol., 58, 725733, 2012

Lenaerts, J. T. M., van den Broeke, M. R., Déry, S. J., KönigLanglo, G., Ettema, J., and Munneke, P. K.: Modelling snowdrift sublimation on an Antarctic ice shelf, The Cryosphere, 4, 179190, doi:10.5194/tc-4-179-2010, 2010.

Mahalinganathan, K., Thamban, M., Laluraj, C. M., and Redkar, B. L.: Relation between surface topography and sea-salt snow chemistry from Princess Elizabeth Land, East Antarctica, The Cryosphere, 6, 505-515, doi:10.5194/tc-6-505-2012, 2012.

Neumann, T. A., Waddington, E. D., Steig, E. J., and Grootes, P. M.: Non-climate influences on stable isotopes at Taylor Mouth, Antarctica, J. Glaciol., 51, 248-258, 2005.

Oerter, H., Wilhelms, F., Jung-Rothenhäusler, F., Göktas, F., Miller, H., Graf, W., and Sommer, S.: Accumulation rates in Dronning Maud Land, Antarctica, as revealed by dielectric-profiling measurements of shallow firn cores, Ann. Glaciol., 30, 27-34, 2000.

Pettre, P., Pinglot, F., Pourchet, M., and Reynaud, L.: Accumulation distribution in Terre Adélie, Antarctica: Effect of meteorological parameters, J. Glaciol., 32, 486-500, 1986.

Popov, S. V. and Eberlein, L.: Investigation of snow-firn thickness and ground in the East Antarctica by means of geophysical radar, Led i Sneg, 4, 95-106, 2014.
Popov, S. V. and Masolov, V. N.: Forty-seven new subglacial lakes in the $0-110^{\circ} \mathrm{E}$ sector of East Antarctica, J. Glaciol., 53, 289297, 2007.

Richardson, C., Aarholt, E., Hamran, S.-E., Holmlund, P., and Isaksson, E.: Spatial distribution of snow in western Dronning Maud Land, East Antarctica, mapped by a ground-based snow radar, J. Geophys. Res., 102, 20343-20353, 1997.

Richter, A., Fedorov, D. V., Fritsche, M., Popov, S. V., Lipenkov, V. Y., Ekaykin, A. A., Lukin, V. V., Matveev, A. Y., Grebnev, V. P., Rosenau, R., and Dietrich, R.: Ice flow velocities over Vostok Subglacial Lake, East Antarctica, determined by 10 years of GNSS observations, J. Glaciol., 59, 315-326, doi:10.3189/2013JOG12J056, 2013.

Rotschky, G., Eisen, O., Wilhelms, F., Nixdorf, U., and Oerter, H.: Spatial distribution of surface mass balance on Amundsenisen Plateau, Antarctica, derived from ice-penetrating radar studies, Ann. Glaciol., 39, 265-270, 2004.

Scambos, T. A., Frezzotti, M., Haran, T. V., Bohlander, J., Lenaerts, J. T. M., Van den Broeke, M. R., Jezek, K., Long, D., Urbini, S., Farness, K., Neumann, T., Albert, M., and Winther, J.-G.: Extent of low-accumulation 'wind-glaze' areas on the East Antarctic plateau: Implications for continental ice mass balance, J. Glaciol., 58, 633-647, 2012.

Schoenemann, S. W., Schauer, A. J., and Steig, E. J.: Measurement of SLAP2 and GISP $\delta^{17} \mathrm{O}$ and proposed VSMOW-SLAP normalization for $\delta^{17} \mathrm{O}$ and ${ }^{17} \mathrm{O}$ excess, Rapid Commun. Mass Spectrom., 27, 582-590, 2013.

Severinghaus, J. P., Albert, M. R., Courville, Z. R., Fahnestock, M. A., Kawamura, K., Montzka, S. A., Mühle, J., Scambos, T. A., Shields, E., Shuman, C. A., Suwa, M., Tans, P., and Weiss, R. F.: Deep air convection in the firn at a zero-accumulation site, central Antarctica, Earth Planet. Sci. Lett., 293, 359-367, 2010.

Swithinbank, C.: Antarctica, US Geol. Survey Prof. Rap., 1386-B, 1988.

Thiery, W., Gorodetskaya, I. V., Bintanja, R., Van Lipzig, N. P. M., Van den Broeke, M. R., Reijmer, C. H., and Kuipers Munneke, P.: Surface and snowdrift sublimation at Princess Elizabeth station, East Antarctica, The Cryosphere, 6, 841-857, doi:10.5194/tc-6841-2012, 2012.

Town, M. S., Warren, S. G., Walden, V. P., and Waddington, E. D.: Effect of atmospheric water vapor on modification of stable isotopes in near-surface snow on ice sheets, J. Geophys. Res., 113, 1-16, 2008.

Van der Veen, C. J., Mosley-Thompson, E., Gow, A., and Mark, B. G.: Accumulation at South Pole: Comparison of two 900-year records, J. Geophys. Res., 104, 31067-31076, 1999.

Vladimirova, D. O. and Ekaykin, A. A.: Climatic variability in Davis Sea sector (East Antarctica) over the past 250 years based on the " $105 \mathrm{~km}$ " ice core geochemical data, Geophys. Res. Abstr., 16, p. 285, 2014.

Whillans, I. M.: Effect of inversion winds on topographic detail and mass balance on inland ice sheets, J. Glaciol., 14, 85-90, 1975. 